\title{
Late follow-up of peripheral neural decompression in leprosy: functional and clinical outcomes
}

\author{
Seguimento tardio da descompressão neural periférica na hanseníase: resultados \\ funcionais e clínicos
}

\begin{abstract}
Liliane Marques de Pinho TIAGO1,2, Maria Fernanda Ferreira BARBOSA ${ }^{1}$, Diogo Fernandes dos SANTOS ${ }^{1,2}$, Adelmo Divino FARIA' ${ }^{1}$, Maria Aparecida GONCALVES'1 , Adeilson Vieira COSTA¹, Isabela Maria Bernardes GOULART $T^{1,2}$
\end{abstract}

\begin{abstract}
Background: Peripheral neural surgical decompression (PNSD) is used as a complementary therapy to the clinical treatment of neuritis to preserve neural function. Objective: To evaluate the long-term (1 year) clinical and functional results for PNSD in leprosy neuritis. Methods: This cross-sectional study included leprosy patients who were in late postoperative period (LPO) of surgical decompression of ulnar, median, tibial, and fibular nerves. Socioeconomic, epidemiological, and clinical data were collected. The following instruments were used in this evaluation: visual analogue pain scale (VAS), Douleur Neuropathique en 4 Questions (DN4), SALSA scale, and simplified neurological assessment protocol. The preoperative (PrO) and 180-day postoperative (P0180) results were compared. Results: We evaluated 246 nerves from 90 patients: 56.6\% were on multidrug therapy (MDT) and 43.3\% discharged from MDT. Motor scores and pain intensity showed statistically significant improvement $(p<0.01)$. There was an increase in sensory scores only for bilateral ulnar nerves ( $p<0.05)$. Of the operated cases, $26.0 \%$ of patients were referred for surgery of ulnar neuritis and $23.6 \%$ of tibial neuritis. Neuropathic pain was reported in $41 \%$ of cases. Daily dose of prednisone reduced from $39.6 \mathrm{mg}( \pm 3.0)$ in PrO, $16.3 \mathrm{mg}( \pm 5.2)$ in P0180, to $1.7 \mathrm{mg}( \pm 0.8)$ in LPO. The SALSA scale results showed mild activity limitation in $51 \%$ and moderate in $34 \%$ of patients. Eighty percent of individuals reported that the results reached their expectations. Conclusions: PNSD in leprosy was effective in the long term to decrease the prevalence and intensity of pain, improve motor function, and reduce the dose of corticosteroids, which is reflected in the patients' satisfaction.
\end{abstract}

Keywords: Leprosy; Decompression, Surgical; Neuralgia; Peripheral Nerves.

\section{RESUMO}

Antecedentes: A descompressão cirúrgica neural periférica (DCNP) é usada como uma terapia complementar ao tratamento clínico da neurite hansênica para preservar a função neural. Objetivo: Avaliar a longo prazo (1 ano) os resultados clínicos e funcionais da DCNP na neurite hansênica. Métodos: Este estudo transversal incluiu pacientes que estavam no pós-operatório tardio (POT) de cirurgia de descompressão dos nervos ulnares, medianos, tibiais e fibulares. Foram coletados dados socioeconômicos, epidemiológicos e clínicos. Os instrumentos utilizados foram: escala visual analógica de dor (EVA), questionário de dor neuropática 4 (DN4), escala SALSA e protocolo de avaliação neurológica simplificada. Os resultados obtidos foram comparados com os do pré-operatório (PrO) e pós-operatório de 180 dias (P0180).

Resultados: Foram avaliados 246 nervos de 90 pacientes: 56,6\% estavam em poliquimioterapia (PQT) e 43,3\% em alta da PQT. Escores motores e intensidade da dor apresentaram melhora significante $(p<0,01)$. Houve aumento nos escores sensitivos nos nervos ulnares bilaterais ( $p<0,05)$. Neurite ulnar foi indicação cirúrgica em 26,0\% dos casos operados, seguida pela neurite tibial (23,6\%). Dor neuropática foi relatada em 41\% dos casos. Dose diária de prednisona reduziu de 39,6 mg ( $\pm 3,0)$ na PrO, $16,3 \mathrm{mg}( \pm 5,2)$ na P0180, para 1,7 mg $( \pm 0,8)$ na POT. Escala SALSA mostrou limitação leve da atividade em $51 \%$ e moderada em $34 \%$ dos pacientes. $80 \%$ dos indivíduos relataram que os resultados atingiram suas expectativas. Conclusão: DCNP na hanseníase foi eficaz a longo prazo na redução da prevalência e intensidade da dor, na melhora da função motora e redução da dose de corticosteroides, refletindo na satisfação do paciente.

Palavras-chave: Hanseníase; Descompressão Cirúrgica; Neuralgia; Nervos Periféricos.

\footnotetext{
'Universidade Federal de Uberlândia, Hospital de Clínicas, Centro Nacional de Referência em Dermatologia Sanitária e Hanseníase, Uberlandia MG, Brazil. ${ }^{2}$ Universidade Federal de Uberlândia, Faculdade de Medicina, Programa de Pós-Graduação em Ciências da Saúde, Uberlandia MG, Brazil. LMPT (D) https://orcid.org/0000-0001-8734-2887; MFFB (D) https://orcid.org/0000-0002-6176-7673; DFS (D) https://orcid.org/0000-0002-3807-9987; ADF (1) https://orcid.org/0000-0001-9639-0696; MAG (1) https://orcid.org/0000-0002-5130-7243; AVC (1) https://orcid.org/0000-0001-5016-0537; IMBG (D) https://orcid.org/0000-0003-2319-3223

Correspondence: Liliane Marques de Pinho Tiago; Email: Lilianeanest@gmail.com.

Conflict of interest: There is no conflict of interest to declare.

Authors' contributions: LMPT, IMBG: conception and design of the research; LMPT, MFFB, ADF, MAG, AVC: data collection, analysis, and interpretation; DFS, IMBG: data analysis and interpretation; LMPT, IMBG: drafting the article; LMPT, MFFB, DFS, MAG, IMBG: critical revision of the manuscript; LMPT, DFS, IMBG: final approval of the version to be published.

Received on January 25, 2020; Received in its final form on September 14, 2020; Accepted on October 22, 2020.
} 


\section{INTRODUCTION}

Leprosy is among the main causes of tractable peripheral neuropathy in the world ${ }^{1}$, with an estimated occurrence of more than 15/100.000 inhabitants in Brazil2. Invasion of Mycobacterium leprae into a nerve leads to either a direct or indirect inflammatory process, termed neuritis, clinically defined when there is some impairment of neural function (sensory and / or motor), with or without pain (silent neuritis) $)^{3}$. The neural impairment is caused not only by the infection, but also by the immune reactions, which can lead to the main sequelae and deformities in this neuropathy, causing serious physical, social, and psychological disorders ${ }^{4}$. The neural damage due to leprosy may occur before and during the course of the disease, even after standard treatment with multidrug therapy (MDT)

The treatment of choice for neuritis is clinical and consists of steroid therapy and limb immobilization ${ }^{5}$. The pain in leprosy neuritis can be nociceptive due to the inflammation process that occurs during episodes of immune systemmediated reactions, or it can also be neuropathic, considering that leprosy may affect the somatosensory system ${ }^{6}$. The prevalence of neuropathic pain in individuals with leprosy is still not well-documented and probably underestimated ${ }^{7}$.

Peripheral neural surgical decompression (PNSD) is used as a complementary therapy to clinical neuritis treatment with the objective of preserving neural function and is not recommended in cases without previous clinical treatment ${ }^{8}$. In some randomized controlled trials, the combination of surgery and medical treatment did not show additional benefit in relation to medical treatment alone $e^{9,10}$. However, after a Cochrane's review of the subject, it was concluded that the results of these studies were not sufficient to evaluate the effects of the surgery, and that new studies with larger populations and with long-term follow-ups were necessary to evaluate the possible favorable predictive factors for decompressive surgery ${ }^{8,11}$. The epidemiological and clinical profiles of these patients make them inappropriate for randomized controlled trials; in addition, non-randomized studies that evaluated the effects of PNSD showed a tendency toward pain relief ${ }^{3,12-14}$.

This study aimed to evaluate the long-term effectiveness (at least one year) of surgical treatment, using assessments of motor and sensory function, degree of functional disability, intensity of pain, prednisone dose, and satisfaction with surgery.

\section{METHODS}

\section{Patients and data collection}

This cross-sectional study selected 90 leprosy patients aged 18 to 80 years and both genders who underwent PNSD with at least one postoperative year, from the National Reference Center for Sanitary Dermatology and Leprosy from January 2010 to May 2014. This study was approved by the Committee of Ethics in Research from the Federal University of Uberlândia (CAE: 235203146.0000.5152). Written informed consent was obtained from all participants.

The PNSD was recommended only in cases where the clinical treatment of neuritis leprosy was ineffective. The following inclusion criteria were adopted for all patients in the study: presence of nerve abscess, neuritis that does not respond to standardized clinical treatment within 4 weeks, with worsening dermatoneurological evaluation, cases of reentrant neuritis (when a new clinical impairment occurs in the attempt to withdraw or reduce the dose of corticosteroids), tibial neuritis with or without the presence of a plantar ulcer, as it could be silent and does not always respond well to corticosteroids and in cases of neuritis associated with other comorbidities that contraindicate the use of corticosteroids.

The clinical treatment of neuritis consisted of maintaining the multidrug therapy (MDT) for patients who were still undergoing treatment against leprosy, immobilization of the affected limb, in a combination with the use of prednisone at a dose of $1 \mathrm{mg} / \mathrm{kg}$ daily for cases of type 1 and 2 reactions and use of thalidomide only for type 2 reactions, and with actions to prevent disabilities, such as motor physical therapy and periodic evaluation with an occupational therapist.

Patients with chronic alcoholism, diabetes mellitus, thyroid disease, hereditary neuropathy, human immunodeficiency virus, autoimmune diseases, or previous injuries were excluded. Epidemiological, socioeconomic, and clinical data were examined. The patients were classified as tuberculoid (TT), borderline-tuberculoid (BT), borderline-borderline (BB), borderline-lepromatous (BL), and lepromatous leprosy $(\mathrm{LL})^{15}$. Data collected in the late post-operative (LPO, $\geq 1$ year) evaluation were compared with those of the preoperative (PrO) and 180-day postoperative (PO180) periods, which was recorded in the medical records.

The perceptions of activity limitation by the patients were evaluated using the Screening of Activity Limitation and Safety Awareness (SALSA scale) at the LPO, which consists of a questionnaire with 20 items divided into five areas involving the eyes, hands (skills and work), feet (mobility), and self-care. The results are classified into several groups: (1) $10-24$ (no limitation of activities); (2) 25 - 39 (mild limitations); (3) 40 49 (moderate limitations); (4) 50 - 59 (severe limitations); and (5) $60-80$ (very severe limitations) ${ }^{16}$.

\section{Neurological evaluation}

All the subjects were submitted to a simplified neurological assessment protocol by the institution's physiotherapy team that is standardized by the Ministry of Health in Brazil and used in all reference centers for leprosy. 
Sensorial evaluation of each nerve was performed using the six Semmes-Weinstein filaments, which exert forces of $0.05,0.2,2,4,10$, and $300 \mathrm{~g}$ on the skin. In the presence of a negative response to the lightest monofilament ( $0.05 \mathrm{~g}$ ), the test was carried out using monofilaments of increasing thickness, i.e. $0.2,2,4,10$, and $300 \mathrm{~g}$, until a positive response was obtained. In the upper limbs, three points were evaluated for the median (points 1, 2, and 3) and ulnar (points 4, 5, and 6) nerves. In the lower limb, nine points were evaluated for the tibial nerve (points 1-9) and one point for the common fibular nerve (point 10). Each of these points received a score that varied from 0 to 5 , with a maximum score of 15 for the median and ulnar nerves, 45 for the tibial nerve and 5 for the common fibular nerve (Figure 1) ${ }^{17}$.

In order to assess motor function, the following muscles were evaluated in the upper limbs: abductor pollicis brevis and lumbricals (first and second) for the median nerve, first dorsal interosseous, abductor digiti minimi, and lumbricals (third and fourth) for the ulnar nerve. In the lower limbs, only the muscles innervated by the deep fibular nerve were assessed (tibial anterior, extensor digitorum longus, and extensor hallucis longus). According to functional condition, scores that ranged from 0 to 5 were assigned on each evaluated muscle as the Medical Research Council scale, with a maximum score of 10 for median nerve, 15 for ulnar nerve, and 15 for common fibular nerve (Chart 1$)^{17}$.

The level of functional disability evaluates the neural function integrity and the degree of physical disability, through voluntary muscle testing and sensorial evaluation of the hands and feet. When there is no neural impairment, patients are classified as disability grade zero (DG0) and when there is only sensorial impairment they are classified as disability grade 1 (DG1). Regarding disability grade 2 (DG2), there are visible deficiencies, such as clawed fingers, bone resorption, muscle atrophy, contractures, and wounds ${ }^{17}$.

Degree of intensity of postoperative pain of each nerve was assessed by using the Visual Analog Scale for Pain (VAS) at the $\mathrm{PrO}$ and $\mathrm{LPO}^{18}$ evaluations. The prevalence of neuropathic pain was evaluated only at the LPO evaluation by applying the questionnaire Douleur Neuropathique en 4 Questions (DN4), a universal instrument validated for Portuguese ${ }^{19}$.

\section{Surgical technique}

Patients undergoing surgery followed the referral protocol and surgical techniques recommended by the Ministry of $\mathrm{Health}^{20}$. The ulnar nerve was approached through the medial face of the elbow with anterior transposition. For the median nerve, the carpal tunnel canal was opened, and adhesions were released along the nerve. For the tibial nerve, the incision was below the medial malleolus with an opening made in the fibrous tunnel for neural decompression. The common fibular nerve was approached through the opening of the fibro-osseous canal in the fibular head with decompression of superficial and deep branches.

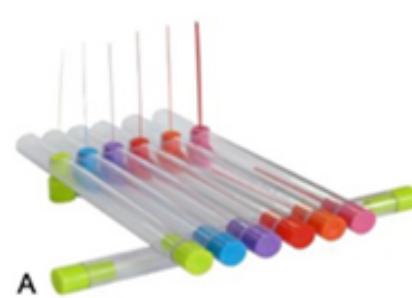

\begin{tabular}{|l|c|c|}
\hline $\begin{array}{c}\text { Semmes-Weinstein esthesiometer } \\
\text { monofilaments }\end{array}$ & Score \\
\hline Green & 0,05 & 5 \\
\hline Blue & 0,2 & 4 \\
\hline Purple & 2,0 & 3 \\
\hline Red & 4,0 & 2 \\
\hline Orange & 10 & 1 \\
\hline Pink & 300 & 0 \\
\hline & No response & 0 \\
\hline
\end{tabular}
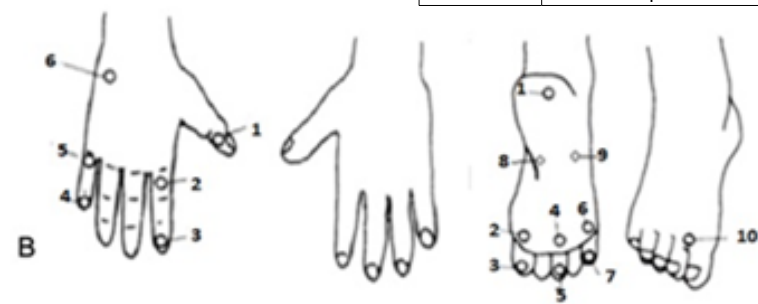

Figure 1. (A) Semmes-Weinstein esthesiometer with six nylon monofilaments of different diameters and the scores attributed to each monofilament: 0.05 g (green); 0.2 g (blue), $2 \mathrm{~g}$ (purple), $4 \mathrm{~g}$ (red), $10 \mathrm{~g}$ (orange) and $300 \mathrm{~g}$ (pink). (B) In the upper limbs, three points were evaluated for the median (points 1, 2 and 3) and ulnar (points 4, 5 and 6) nerves. In the lower limb, nine points were evaluated for the tibial nerve (points 1-9) and one point for common fibular nerve (point 10). Each of these points received a score that varied from 0 to 5 , with a maximum score of 15 for median and ulnar nerves, 45 for the tibial nerve, and 5 for the common fibular nerve.

Chart 1. Medical Research Council (MRC) muscle grading scale with scores for assessment of motor strength.

\begin{tabular}{clc}
\hline Grade & \multicolumn{1}{c}{ Description } & Score \\
\hline 5 & $\begin{array}{l}\text { Full range of movement at the joint with } \\
\text { normal resistance }\end{array}$ & 5 \\
\hline 4 & $\begin{array}{l}\text { Full range of movement but with less } \\
\text { resistance }\end{array}$ & 4 \\
\hline 3 & $\begin{array}{l}\text { Full range of movement with no } \\
\text { resistance }\end{array}$ & 3 \\
\hline 2 & $\begin{array}{l}\text { Perceptible contration of muscles not } \\
\text { resulting in joint moviments }\end{array}$ & 2 \\
\hline 1 & $\quad$ Complete paralysis & 1 \\
\hline 0 & & 0 \\
\hline
\end{tabular}

Considering that leprosy neuropathy manifests as an asymmetrical multiple mononeuropathy and that the risk of recurrence and involvement of other neural trunks in the ipsilateral limb is high during reaction episodes, neural decompression surgery is always performed in a combined manner: median and ulnar nerves when operating on the upper limbs, and when operating on the lower limbs, the fibular and the tibial nerves are decompressed in the same surgical procedure. Decompression is always performed on the most affected limb and never simultaneously, considering the need for limb immobilization and the need for early rehabilitation.

\section{Statistical analysis}

Non-parametric tests were used, and normality tests for quantitative variables indicated that these did not follow a normal distribution $(\mathrm{p}<0.05)$. Therefore, McNemar's test 
was used for comparisons between PrO and LPO for qualitative data and Wilcoxon's test for quantitative data. The comparisons among PrO, PO180, and LPO was also done with Friedman's test. All the tests were done with software SPSS (v20), and a level of significance of $5 \%$ was accepted.

\section{RESULTS}

\section{Clinical and socioeconomic characteristics}

The socioeconomic variables, clinical classification, and operational classification of patients are described in Table 1. Among patients included in this study, $78.9 \%$ (71/90) were multibacillary (MB) and BT clinical form was the most prevalent $(38.9 \% ; 35 / 90)$. Regarding the time of surgical referral, 56.6\% (51/90) of patients were submitted to PNSD during treatment with MDT and 43.3\% (39/90), after the end of treatment. In this group, the average time between the end of treatment and surgery was 33.27 months $( \pm 27.68)$ (median $=19$ months).

A total of 246 nerves (123 surgical procedures) were operated on 90 patients, with an average of 2.7 nerves per patient. There was a greater recommendation of surgical procedure on the nerves of the upper limbs, with combined median and

Table 1. Demographic data, including socio-economic and clinical variables.

\begin{tabular}{|c|c|c|}
\hline Variable & $\mathrm{N}=90$ & $\%$ \\
\hline \multicolumn{3}{|l|}{ Gender } \\
\hline Female & 31 & 34.4 \\
\hline Male & 59 & 65.6 \\
\hline \multicolumn{3}{|l|}{ Age (years) } \\
\hline 23 a 34 & 11 & 12.2 \\
\hline 35 a 46 & 33 & 36.7 \\
\hline 47 a 58 & 28 & 31.1 \\
\hline 59 a 70 & 14 & 15.6 \\
\hline$>70$ & 4 & 4.4 \\
\hline \multicolumn{3}{|l|}{ Occupational status } \\
\hline Active & 28 & 31.1 \\
\hline Retired & 46 & 51.1 \\
\hline Sick leave & 16 & 17.8 \\
\hline \multicolumn{3}{|l|}{ Type of Retirement } \\
\hline Disability & 32 & 69.5 \\
\hline Age & 14 & 30.4 \\
\hline \multicolumn{3}{|l|}{ Clinical classification } \\
\hline Lepromatous & 10 & 11.1 \\
\hline Borderline-lepromatous & 19 & 21.1 \\
\hline Borderline-borderline & 15 & 16.7 \\
\hline Borderline-tuberculoid & 35 & 38.9 \\
\hline Tuberculoid & 11 & 12.2 \\
\hline
\end{tabular}

$\mathrm{N}$ : number of cases; \%: percentage of cases. ulnar decompression in 57.6\% (142/246) of the cases. Around $77 \%$ (69/90) of individuals were operated on only one limb (two nerves), $14.4 \%$ (13/90) were operated on two limbs (four nerves), 4.4\% (4/90) were operated on three limbs (six nerves), and $4.4 \%$ (4/90) were operated on four limbs (eight nerves).

Isolated ulnar neuritis was responsible for surgical referral in $26.0 \%(32 / 123)$ of operated cases, followed by isolated tibial neuritis in $23.6 \%$ (29/123). The remaining cases had more than a single altered nerve at the time of surgical referral. Only $2.2 \%$ of individuals (2/90) presented complications in the immediate postoperative period, requiring a new surgical approach. After PNSD, 14.4\% (13/90) presented at least one immune reaction episode.

\section{Patient perception}

Regarding the patients' perception of the surgery, $80 \%$ (72/90) of individuals reported that the results reached their expectations; $16.7 \%$ (15/90) expected better results with the surgery, and $3.3 \%$ (3/90) reported that the surgery did not meet their expectations and the results were worse than expected.

In assessing the limitations of functional capacity according to the SALSA scale, 10\% (9/90) of individuals did not have limitations in activity performance, $51.2 \%$ (46/90) had mild limitations, $34.4 \%$ (31/90) had moderate limitations, $3.3 \%$ (3/90) were severe, and $1.1 \%(1 / 90)$ presented very severe limitations.

\section{Pain assessment}

In $\mathrm{PrO}, 74.4 \%(67 / 90)$ of individuals presented pain, and at the LPO, 55.5\% (50/90). At this time, 74\% (37/50) of these patients presented characteristics of neuropathic pain according to DN4. When the average intensity of pain by VAS was compared for the PrO and the LPO periods, a significant difference was noticed, indicating a significant reduction in pain intensity $(\mathrm{p}<0.001)$ (Figure 2).

\section{Prednisone dosage}

At the time of surgical referral, 43.3\% (39/90) of patients were using high-dose prednisone ( $1 \mathrm{mg} / \mathrm{kg}$ daily) for more than 6 months and 52.2\% (47/90) reported some adverse effect of the chronic use of corticosteroids. Only $15.5 \%$ (14/90) of the individuals maintained the use of prednisone in the POT. The mean dose of prednisone used was $39.6 \mathrm{mg}( \pm 3.0)$ in PrO, 16.3 $\mathrm{mg}( \pm 5.2)$ in PO180 and $1.7 \mathrm{mg}( \pm 0.8)$ in LPO. The reduction in prednisone dose was statistically significant when the $\mathrm{PrO}$ dose was compared to PO180 and LPO (p<0.001) (Figure 3).

\section{Neurological assessment and incapacity level}

There was a significant increase in the motor score in all of the nerves that underwent surgery, except for the left fibular nerve (Table 2), when comparing the three study periods (PrO, PO180, and LPO). 


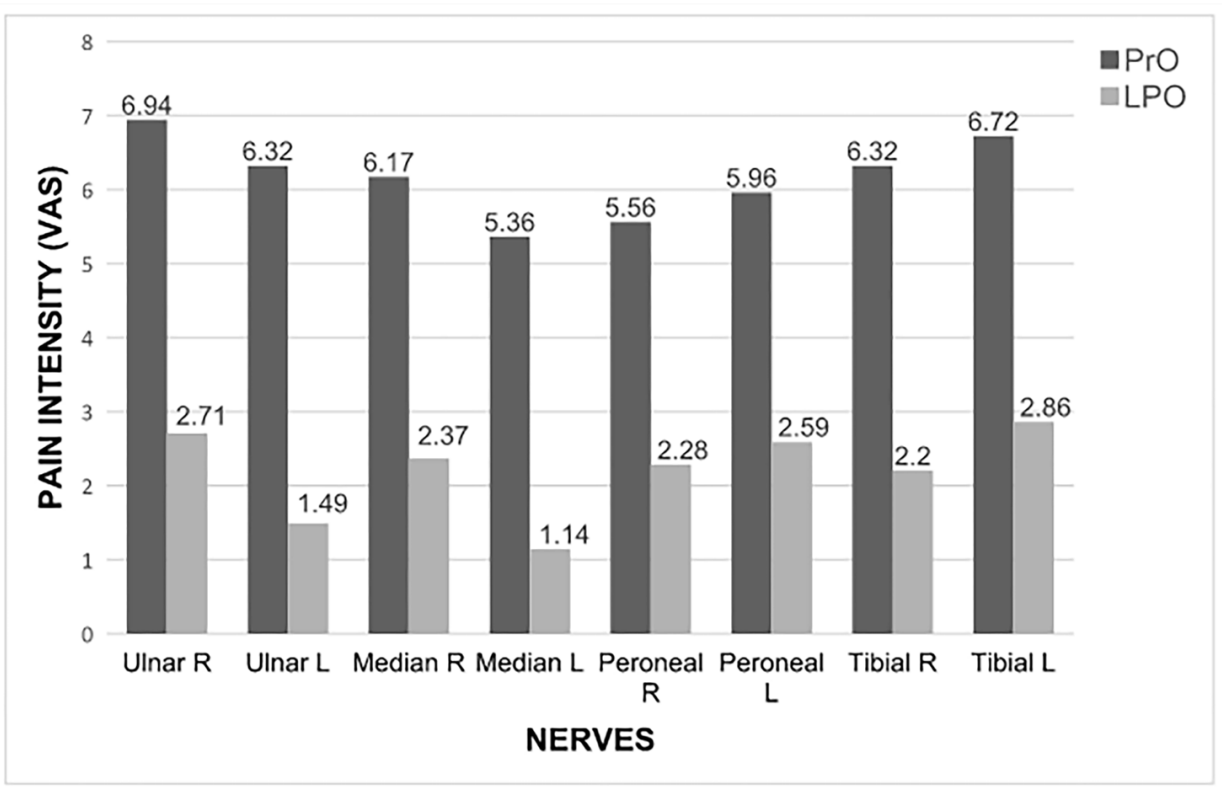

Figure 2. ${ }^{*} p<0.001$.

Average pain intensity (VAS) in the preoperative (PrO) and late postoperative periods (LPO) in each of the operated nerves. There was a reduction in pain intensity in all operated nerves.

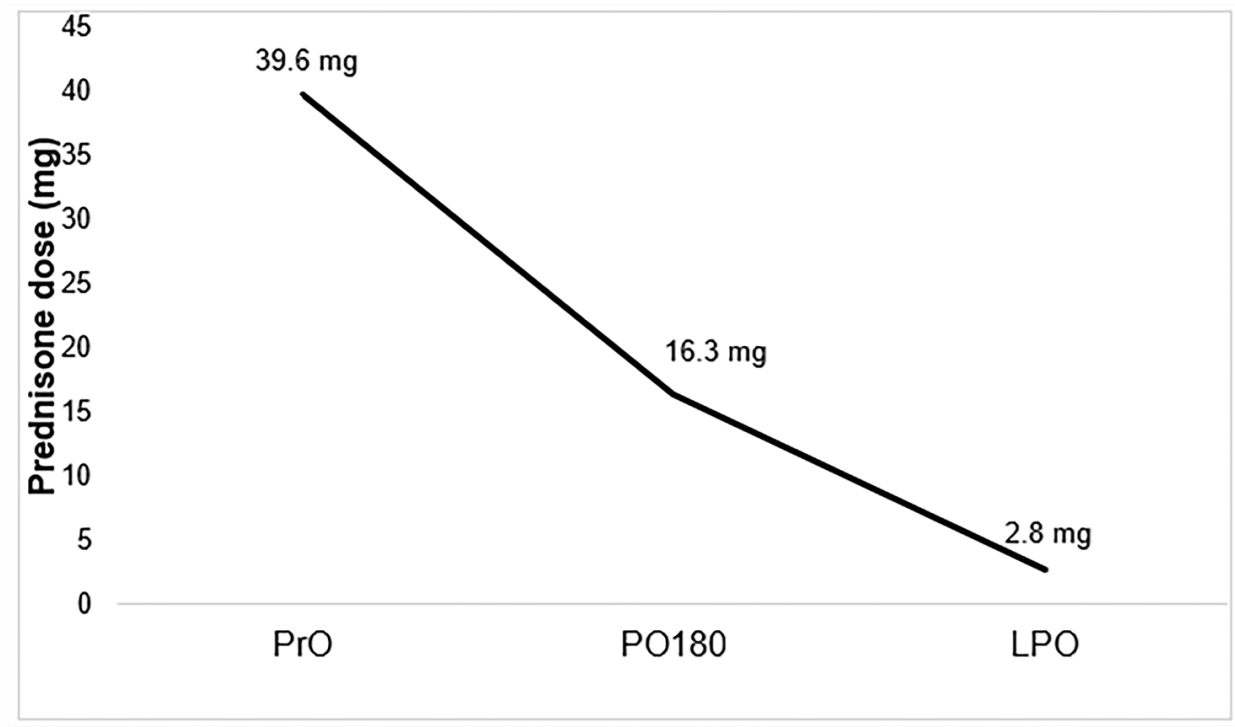

Figure 3. The mean dose of prednisone in $\mathrm{mg}$ showed a significant reduction $(\mathrm{p}<0.01)$ between the preoperative period $(\mathrm{PrO})$, the postoperative period of 180 days (P0180) and the late postoperative period (LPO) $(p<0.001)$.

When the sensory score of the nerves that underwent surgery were compared during the three study periods ( $\mathrm{PrO}$, PO180, and LPO), an improvement in the left right fibular and tibial nerves was noted comparing the PrO with PO180, but no improvement was found when comparing only the $\mathrm{PrO}$ with LPO (Table 2). However, regarding the ulnar nerves, a significant improvement $(\mathrm{p}<0.05)$ was observed when comparing the PrO with PO180 and also with LPO.

Considering the evaluation of the DG in the PrO, $47.3 \%$ (17/36) of left upper limbs, $57.1 \%$ (20/35) of right upper limbs, $62.9 \%(17 / 27)$ of left lower limbs, and 52.2\% (13/25) of right lower limbs presented DG2. During the LPO period, there was a reduction in the DG in all assessed limbs, but with significance only in the right lower limbs $(\mathrm{p}=0.001)$.

\section{DISCUSSION}

The sample had a preponderance of men, mostly in the economically active age range, which corresponded with results from previous studies ${ }^{3,21}$. According to the operational classification, there was a higher number of multibacillary and borderline-tuberculoid in clinically diagnosed patients, considering that this is an endemic area ${ }^{22}$. In the borderline forms, many nerve branches are affected, and the deformities due to neural damage are the worst $\mathrm{t}^{23}$. The ulnar nerve is the most frequently affected in leprosy ${ }^{24,25}$, which justifies the high incidence of surgery in the upper limbs in this study.

Between 15 and $65 \%$ of leprosy patients presented irreversible neural damage during the course of the disease, 
Table 2. Means, standards deviation and comparison of the sensory and motor scores of the operated nerves in the PrO, P0180, and LPO periods.

\begin{tabular}{|c|c|c|c|c|c|c|}
\hline \multicolumn{7}{|c|}{ Sensory Score } \\
\hline & PrO & P0180 & Wilcoxon* & LPO & Wilcoxon** & Friedman \\
\hline Nerve & Mean $\pm S D$ & Mean $\pm S D$ & $p$ valor & Mean $\pm S D$ & $p$ valor & p valor \\
\hline Ulnar L & $6.9 \pm 5.1$ & $8.0 \pm 6.0$ & 0.123 & $8.58 \pm 5.0$ & $0.026^{*}$ & 0.371 \\
\hline Median L & $10.4 \pm 5.2$ & $11.6 \pm 4.7$ & $0.028^{*}$ & $11.5 \pm 4.5$ & 0.088 & 0.234 \\
\hline Ulnar R & $5.6 \pm 5.0$ & $7.0 \pm 5.3$ & $0.025^{*}$ & $7.4 \pm 5.5$ & $0.048^{*}$ & 0.422 \\
\hline Median R & $10.4 \pm 5.7$ & $11.5 \pm 4.6$ & 0.081 & $11.4 \pm 5.2$ & 0.106 & 0.192 \\
\hline Tibial R & $10.2 \pm 10.6$ & $14.6 \pm 12.8$ & $0.004^{*}$ & $14.2 \pm 14.3$ & 0.080 & $0.036^{\star}$ \\
\hline Fibular R & $1.3 \pm 1.9$ & $1.8 \pm 2.1$ & $0.032^{*}$ & $1.5 \pm 1.8$ & 0.262 & $0.049^{*}$ \\
\hline Tibial L & $8.0 \pm 11.1$ & $11.1 \pm 13.9$ & $0.041^{*}$ & $9.0 \pm 12.5$ & 0.477 & $0.048^{*}$ \\
\hline Fibular L & $1.04 \pm 2.0$ & $1.46 \pm 2.24$ & 0.093 & $1.0 \pm 1.5$ & 0.778 & 0.340 \\
\hline \multicolumn{7}{|c|}{ Motor Score } \\
\hline & PrO & P0180 & Wilcoxon* & LPO & Wilcoxon** & Friedman \\
\hline Nerve & Mean $\pm S D$ & Mean $\pm S D$ & $p$ valor & Mean $\pm S D$ & $p$ valor & p valor \\
\hline Ulnar L & $8.3 \pm 3.7$ & $9.9 \pm 3.9$ & $0.001^{*}$ & $11.4 \pm 3.5$ & $0.000^{\star}$ & $0.001^{*}$ \\
\hline Median L & $7.5 \pm 2.0$ & $8.4 \pm 1.8$ & 0.003 & $8.8 \pm 1.6$ & $0.000^{*}$ & $0.001^{*}$ \\
\hline Ulnar R & $7.3 \pm 3.2$ & $8.7 \pm 3.9$ & $0.006^{*}$ & $9.4 \pm 3.6$ & $0.000^{*}$ & $0.001^{*}$ \\
\hline Median R & $6.5 \pm 2.3$ & $7.6 \pm 2.1$ & $0.018^{*}$ & $8.7 \pm 1.5$ & $0.000^{*}$ & $0.001^{*}$ \\
\hline Fibular L & $9.7 \pm 5.8$ & $10.1 \pm 5.4$ & 0.313 & $10.2 \pm 5.2$ & 0.497 & 0.274 \\
\hline Fibular R & $10.5 \pm 5.0$ & $12.5 \pm 4.0$ & $0.024^{*}$ & $13.2 \pm 3.6$ & $0.007 *$ & $0.010^{*}$ \\
\hline
\end{tabular}

PrO: preoperative period; P0180: 180 days postoperative period; LPO: late postoperative period; L: Left; R: right; SD: standard deviation; *Wilcoxon test used to compare PrO with P0180; **Wilcoxon test was used to compare PrO with LPO; Friedman test was used to compare the three periods; $*$ Values of p<0.05 indicate a statistically significant correlation.

which occurs principally during the reactional episodes ${ }^{26}$. In our study, most patients underwent PNSD due to the lack of response to medical treatment during reactional episodes, justifying the high incidence of adverse effects related to chronic use of corticosteroids. In addition, the presence of deformities and neural sequelae already at the time of PNSD, reinforces not only the late referral for surgical treatment, but also the difficulty of referring these patients to centers that perform this procedure.

It is important to emphasize that in some cases, even after PNSD, patients can still present new reaction episodes, reinforcing the need for a strict clinical monitoring in the postoperative period. Besides that, a considerable proportion of the patients included in this study underwent the surgical procedure many months after the end of treatment, corroborating the presence of permanent sequelae and less chance of recovery.

Even considering that not all patients had improved sensory-motor function, the stabilization of the process, without worsening symptoms, was one of the reasons for which the patient's expectations were met. When confronting these results with those of the SALSA scale, it was observed that this satisfaction could also be explained due to absence of limitations or mild limitations in the performance of daily life activities found in almost $60 \%$ of patients during the LPO period $^{16}$.
Another factor that contributed to most patients considering the surgery satisfactory was the reduction in pain intensity. In the individuals evaluated, a sharp drop in pain intensity was found when the PrO pain was compared to LPO pain, similar to results of other studies ${ }^{3,12-14}$. However, a considerable proportion of patients presented neuropathic pain during the LPO period, reinforcing the need to optimize pain treatment in these patients, including differentiating between chronic pain and new reaction episodes.

There are various pathogenic mechanisms involved in the origin of neuropathic pain in leprosy, such as acute neural inflammation and trapped nerves, leading to activation of the nerve fibers that innervate the neural sheaths (nervi nervorum $)^{27}$. The development of chronic neuropathic pain in patients whose infections were treated successfully contributes to an unsatisfactory quality of life ${ }^{28}$. In previous studies, the incidence of neuropathic pain in patients who were undergoing clinical treatment was $56.1 \%$, and most patients reported severe pain that interfered with their daily activities $^{29}$. In another study, the incidence of pain was $29 \%$, of which half of the patients presented moderate pain $^{30}$. These studies show that neuropathic pain is an important complication of leprosy neuritis without considering the type of treatment and certainly needs to be addressed in this group of patients. 
Reduction of postoperative prednisone dose in both analyzed periods suggests that corticosteroid was used in high doses probably because the medication could not reach the swollen and ischemic nerves, and that the present symptoms would be related to the external compression of the nerves ${ }^{3}$. The reduction in prednisone dose would lead to a lower incidence of adverse reactions, which is desirable in medical treatment, and thus decreasing the morbidity and mortality related to corticosteroid use $\mathrm{e}^{31-32}$.

When assessing sensory function during the LPO period, there was no substantial improvement of scores, especially in the lower limbs, reinforcing the problem of late surgical referral, when most patients already had a marked sensory impairment in the assessment of disability degree, which can also indicate an irreversible loss of sensations at the time of surgery referral ${ }^{33}$. Neural impairment in leprosy is predominantly sensorial in the early stages of the disease, and these nerve fibers are injured earlier during the course of leprosy in relation to motors fibers ${ }^{34,35}$. This data reinforces the importance of timely treatment during reaction episodes and the need to refer patients to evaluation of surgical treatment at earlier stages.

In relation to motor function, there was an improvement in all the nerves that underwent surgery ${ }^{36,37}$, except for the left fibular, which did not present the same level of recovery. We can conclude that the motor result was favorable, in contrast to sensory function, reinforcing that even with late referral, the surgery obtained satisfactory results and can contribute to a functional improvement of patients.

The data obtained in this study reinforce the importance of monitoring patients affected by leprosy, not only during treatment, but also after discharge. Among multibacillary patients, who are the majority of new cases in Brazil, the frequency of DG2 is still high, between 33 and $56 \%^{38}$. The DG on admission to the health service is considered a predictor of disability progress and reinforces the need for an early diagnosis to prevent neural damage ${ }^{39}$. In this study, a large number of individuals were multibacillary, and more than half already presented DG2 in one of the extremities when there was recommendation for PNSD, which can justify a less than meaningful improvement in all nerves.

There is a lack of consensus about the exact moment for carrying out PNSD for treatment of leprous neuritis, which has led the teams of the Reference Centers to refer patients for this procedure only when there is the threat of irreversible motor neural damage. The results of this study show that PNSD in leprosy is effective in the long-term, especially in decreasing prevalence and the intensity of the pain. It also improves motor function and reduces the dosage of corticosteroid, all of which are reflected in the patients' satisfaction with the surgery.

The pathogenesis of the peripheral nervous system involvement in leprosy is based on two main concepts around which neural damage is better understood: the infection of Schwann cells and the presence of perineural inflammation, resulting from different mechanisms related to the interaction between $M$. leprae and the host. In reaction episodes, the bacillus causes peripheral neuropathy of mainly inflammatory and immunological origin, comprising the action of antibodies, cytotoxicity, and other mechanisms that can result in motor, sensory, and autonomic impairment. However, neural involvement can also result from edema and local mechanical processes, as the involvement of Schwann cells and the presence of neural thickening can make neural fibers more susceptible to compressive effects and the edema of nerve trunks, which can even lead to an ischemic impairment. Therefore, PNSD should be a treatment option for cases of neuritis refractory for clinical treatment.

Considering that reaction episodes represent the main cause of disability in leprosy, medical and surgical treatment of patients with leprosy neuritis should be optimized in leprosy-endemic countries. This study performed a retrospective analysis and did not evaluate new possibilities in the medical treatment of neuritis, such as the use of endovenous corticosteroid for cases of greater severity, or the use of immunosuppressants in individuals who are on a prolonged use of prednisone. The ideal study model to observe the impact of the PNDS would be to assess whether there is a difference in the evolution of groups that underwent the procedure or not, preferably by evaluators who do not know which patients underwent the procedure.

This study reinforces the need for a review of the parameters used in the sensory-motor assessment performed routinely at leprosy reference centers and adopted as part of the PNSD referral criteria. In addition, the clinical heterogeneity of the patients included in the study regarding the duration of the disease, the number and type of reaction episodes, could influence the use of corticosteroids and also the physical examination findings, therefore influencing the results obtained.

In relation to the PNSD, future studies should propose an earlier intervention in individuals without sequelae and permanent deformities that could be guided not only by clinical parameters, but also through electroneuromyography that could evidence the presence of conduction block, temporal dispersion, and other objective neurophysiological findings and by ultrasound of peripheral nerves that could more accurately locate compression sites, making the assessment more objective and accurate.

\section{ACKNOWLEDGMENTS}

The authors thank the team from CREDESH/HC/UFU for the high quality assistance and support to the research committed to the betterment of life conditions of this population affected by leprosy. 
1. Berkowitz AL, Raibagkar P, Prott BS, Mateen FJ. Neurologic manifestations of the neglected tropical diseases. J Neurol Sci. 2015 Feb 15;349(1-2):20-32. https://doi.org/10.1016/j.jns.2015.01.001

2. Ministério da Saúde - Brasil. Sistema de informação de agravos de notificações. Hanseníase. Vigilância Epidemiológica. 2015. Available from: http://www.saude.gov.br/sinam_net

3. Jambeiro JES, Barbosa Júnior AA, Reis MG, Guedes A, Cordeiro Neto AT. Avaliação da neurólise ulnar da neuropatia hansênica. Acta Ortop Bras. 2008 Nov 14;16(4):207-13. https://doi.org/10.1590/S141378522008000400004

4. Scollard DM, Adams LB, Gillis TP, Krahenbuhl JL, Truman RW, Williams DL. The continuing challenges of leprosy. Clin Microbiol Rev. 2006 Apr;19(2):338-81. https://doi.org/10.1128/CMR.19.2.338-381.2006

5. Garbino JA, Nery JA, Virmond M, Stump PRN, Baccarelli R, Marques Jr W. Hanseníase: diagnóstico e tratamento da neuropatia. Rev Assoc Med Bras. 2003 Jul 4;1-13.

6. Haroun OMO, Hietaharju A, Bizuneh E, Tesfaye F, Brandsma WJ, Haanpää M, et al. Investigation of neuropathic pain in treated leprosy patients in Ethiopia: a cross-sectional study. Pain. 2012 Aug;153(8):1620-4. https://doi.org/10.1016/j.pain.2012.04.007

7. Raicher I, Stump PRNAG, Baccarelli R, Marciano LHSC, Ura S, Virmond MCL, et al. Neuropathic pain in leprosy. Clin Dermatol. 2016 Jan-Feb;34(1):59-65. https://doi.org/10.1016/j. clindermatol.2015.10.012

8. Van Veen NHJ, Schreuders TAR, Theuvenet WJ, Agrawal A, Richardus $\mathrm{JH}$. Decompressive surgery for treating nerve damage in leprosy: a cochrane review. Lepr Rev. 2009;80(1):3-12.

9. Ebenezer M, Andrews P, Solomon S. Comparative trial of steroids and surgical intervention in the management of ulnar neuritis. Int J Lepr Other Mycobact Dis. 1996 Sep;64(3):282-6.

10. Boucher P, Millan J, Parent M, Moulia-Pela JP. Randomized controlled trial of medical and medico-surgical treatment of Hansen's neuritis. Acta Leprol. 1998;11(4):171-7.

11. Duerksen F.A hanseníase e a neuropatia através da perspectiva de um cirurgião. Hansenol Int.2004;29(1):46-50.

12. Debray M, Hanslik T, Avansi MA, Pabion B, Lortholary O. Traitement chirurgical de décompression des névrites lépreuses à l'hôpital Bom-Pastor (Amazonie brésilienne). Rev Med Interne. 2001 Dec;22(12):1188-95. https://doi.org/10.1016/S0248-8663(01)004908

13. Pondé JM, da Silva MAF, Barreto IB, Ramos CC. Neurólise ulnar sob anestesia local em pacientes com hanseníase. Arq Bras Neurocir. 2010 Sep;29(3):99-102.

14. Pondé JM, Ramos C, Santos L, Magalhães JP, Cavalcanti AF. Minimally invasive carpal tunnel surgery in leprosy. Arq Bras Neurocir. 2014;33(1):42-4.

15. Ridley DS, Jopling WH. Classification of leprosy according to immunity: a five-group system. Int J Lepr Other Mycobact Dis. 1966 Jul-Sep;34(3):255-73.

16. Salsa Collaborative Study Group. The development of a short questionnaire for screening of activity limitation and safety awareness (SALSA) in clients affected by leprosy or diabetes. Disabil Rehabil. 2007 May 15;29(9):689-700. https://doi. org/10.1080/09638280600926587

17. Brasil, Ministério da Saúde, Secretaria de Vigilância em Saúde, Departamento de Vigilâncias das Doenças Transmissiveis. Diretrizes para vigilância, atenção e eliminação da Hanseníase como problema de saúde pública: manual técnico-operacional. Brasília (DF): Ministério da Saúde; 2016. 58p.

18. Huskisson EC. Measurement of pain. Lancet. $1974 \mathrm{Nov}$ 9;2(7889):1127-31. https://doi.org/10.1016/S0140-6736(74)90884-8

19. Santos JG, Brito JO, de Andrade DC, Kaziyama VM, Ferreira KA, Souza I, et al. Translation to portuguese and validation of the Douleur Neuropathique 4 questionnaire. J Pain. 2010 May;11(5):484-90. https://doi.org/10.1016/j.jpain.2009.09.014

20. Brasil, Ministério da Saúde, Secretaria de Políticas de Saúde,
Departamento de Atenção Básica. Manual de cirurgias. 1st ed. Brasília (DF): Ministério da Saúde; 2002.96p.

21. Rolim MA, Colvero L de A, Machado AL, Pereira AJ, Helene LMF. Significados associados à hanseníase pelos hansenianos. Hansen Int. 2006;31(2):7-14.

22. Goulart IMB, Santos MS, Muniz DLO, Barbosa FM, Cardoso Netto J, Chaves JGM, et al. Caracterização da endemia hansênica no município de Uberlândia - Minas Gerais, Brasil 1996-2000. Hansen Int. 2006;31(1):33-40.

23. Job CK. Nerve damage in leprosy. Int J Lepr Other Mycobact Dis. 1989 Jun;57(2):532-9.

24. Redondo A. Peripheral nerve surgery in leprosy. Neurochirurgie. 2009 Oct;55(4-5):421-6. https://doi.org/10.1016/j.neuchi.2009.09.003

25. Batista KT, de Araújo HJ, da Paz Júnior AC. Resultados da descompressão e anteriorização do nervo ulnar no cotovelo. Rev Bras Cir Plást. 2011 Mar;26(1):134-9. https://doi.org/10.1590/S198351752011000100024

26. Reibel F, Cambau E, Aubry A. Update on the epidemiology, diagnosis, and treatment of leprosy. Med Mal Infect. 2015 Sep;45(9): 383-93. https://doi.org/10.1016/j.medmal.2015.09.002

27. Hietaharju A, Croft R, Alam R, Birch P, Mong A, Haanpää M. Chronic neuropathic pain in treated leprosy. Lancet. 2000 Sep 23;356(9235):1080-1. https://doi.org/10.1016/S01406736(00)02736-7

28. Garbino JA, Heise CO, Marques Jr W. Assessing nerves in leprosy. Clin Dermatol. 2016 Jan-Feb;34(1):51-8. https://doi.org/10.1016/j. clindermatol.2015.10.018

29. Stump PRNAG, Baccarelli R, Marciano LHSC, Lauris JRP, Teixeira MJ, Ura S, et al. Neuropathic pain in leprosy patients. Int J Lepr Other Mycobact Dis. 2004 Jun;72(2):134-8. https://doi.org/10.1489/1544581X(2004)072<0134:NPILP>2.0.CO;2

30. Saunderson P, Bizuneh E, Leekassa R. Neuropathic pain in people treated for multibacillary leprosy more than ten years previously. Lepr Rev. 2008 Sep;79(3):270-6.

31. de Brito EOX, Queen SMF, Pires CAA, Daxbacher ELR. Trombose venosa profunda em um paciente com reação hansênica em uso de talidomida e corticoide: um raro efeito adverso? Hansen Int. 2010;35(1):53-6.

32. Costa AV, Gonçalves MA, Goulart IMB. Perfil dos indivíduos notificados com hanseníase que foram a óbito no município de Uberlândia/MG de 2000-2010. Hansen Int. 2011;36(1):159.

33. Virmond $\mathrm{M}$ da CL, Curry Filho M. Tratamento cirúrgico nos membros superiores e inferiores. In: Alves ED, Ferreira TL, Ferreira IN orgs. Hanseníase: avanços e desafios. Brasília (DF): NESPROM; 2014. p. 305-332.

34. Husain S, Kumar A, Yadav VS, Malaviya GN. Ulnar and median nerves in paucibacillary leprosy--a follow-up study of electrophysiological functions in patients before and after nerve trunk decompression. Lepr Rev. 2003 Dec;74(4):374-82.

35. Orsini M, de Freitas MRG, Antonioli R de S, de Mello MP, Reis JPB, Silva JG, et al. Estudos clínicos, imunopatológicos e eletrofisiológicos dos nervos periféricos na hanseníase. Rev Neurocienc. 2008 Sep 30;16(3):220-30. https://doi.org/10.34024/rnc.2008.v16.8636

36. Dellon AL. Multiple crush concept applied to multiple nerves in leprous neuropathy. Clin Podiatr Med Surg. 2016 Apr;33(2):203-17. https://doi.org/10.1016/j.cpm.2015.12.009

37. Wan EL, Rivadeneira AF, Jouvin RM, Dellon AL. Treatment of peripheral neuropathy in leprosy: the case for nerve decompression. Plast Reconstr Surg Glob Open. 2016 Mar 17;4(3):e637. https://doi. org/10.1097/GOX.0000000000000641

38. Van Brakel WH. Peripheral neuropathy in leprosy and its consequences. Lepr Rev. 2000 Dec;71 Suppl:146-53. https://doi. org/10.5935/0305-7518.20000086

39. Gonçalves SD, Sampaio RF, Antunes CMF. Fatores preditivos de incapacidades em pacientes com hanseníase. Rev Saúde Pública. 2009 Apr;43(2):267-74. https://doi.org/10.1590/S003489102009000200007 